\title{
DOI https://doi.org/10.30525/978-9934-26-178-7-39
}

\section{ЗАСТОСУВАННЯ ФІРМОВОГО СТИЛЮ АВІАКОМПАНІЇ ПРИ ПРОЄКТУВАННІ САЙТУ ТА МОБІЛЬНОГО ДОДАТКУ}

\author{
Борисова С. B. \\ кандидат педагогічних наук, доцент, \\ дочент кафедри дизайну \\ Циганок М. М. \\ студент II курсу магістратури кафедри дизайну \\ Луганський національний університет імені Тараса Шевченка \\ м. Старобільськ, Луганська область, Украӥна
}

Фірмовий стиль визначається як комплекс сталих елементів, до яких відносять шрифт, художньо-графічне зображення та колір для забезпечення єдності та неповторного вигляду компанії, ii товарів та послуг, їх впізнаваності та запам'ятовуваності, і як наслідок формування довіри. І. В. Продан зазначає, що необхідно не менш, ніж 15-20 зорових контактів, для того, щоб відбулося запам'ятовування образу потенційним споживачем, а рекламні повідомлення компанії, які вирішені у фірмових кольорах, споживач узагальнює і таким чином асоціює вже знайомий образ з компанією [1]. Отже, фірмовий стиль формує у споживачів уявлення про приналежність носія фірмового стилю до певної компанії. Його головною метою є дати зрозуміти потенційному споживачу місію, цінності, індивідуальність бренду.

Дизайн фірмового стилю або проєктування фірмового дизайну - це процес створення візуальних проявів фірмового стилю компанії та конкретних об'єктів дизайну, що є носіями цього стилю. Основними елементами фірмового стилю є: логотип, колірна палітра (фірмові кольори), фірмові шрифти [2].

Існують різноманітні класифікації логотипів. В наступному аналізі ми спиралися на класифікацію за семіотичним напрямком, згідно якої логотипи поділяються в залежності від природи елементів: лінгвістичної та / або іконічної на: 1) лінгвістичні, що складаються з літер, слів, цифр та їх комбінації; 2) іконічні, що виражені за допомогою зображень; 3) комбіновані, в яких застосовано поєднання лінгвістичних та зображальних елементів [3, с. 74-75].

Важливим $є$ коректний вибір фірмових кольорів, оскільки вони $є$ провідними елементами фірмового дизайну і відіграють функцію комунікації між компанією і споживачем. Колір робить елементи 
фірмового дизайну не тільки більш привабливими, але й викликає у споживача заплановані для сприйняття компанії емоції через підсвідомий вплив і так само, як і логотип, сприяє кращому запам'ятовуванню компанії. Шрифт також володіє емоційним забарвленням i може сприйматися як легкий, важкий, діловий тощо. Крім вимоги відповідності емоції профілю роботи компанії шрифт має бути добре зчитуваним, що залежить від гарнітури шрифта, його кеглю, накреслення. Тому на сьогодні при виборі шрифта перевага віддається максимально простим, чітким, таким, що добре сприймаються при зчитуванні, навіть з відстані.

Надання послуг авіакомпаніями в Інтернеті- досить поширене явище. Інтернет $\epsilon$ основним ринком, на якому функціонують такі популярні авіалінії, як Qatar Airways, Singapore Airlines, Emirates, Lufthansa. Щодо українського ринку, то тут представлені такі компанії, як Авіакомпанія МАУ, Turkish Airlines, Wizz Air Hungary, SkyUp, LOT, Ryanair, Azur Air Ukraine тощо [4]. Кожна з них має на меті отримання прибутку від реалізації своїх послуг. При насиченості ринку певним видом послуг, авіапослуг, зокрема, унікальний фірмовий стиль $є$ тим засобом, який не дає компанія загубилася серед конкурентів, робить бренд або компанію конкурентоспроможною, впізнаваною, унікальною.

Аналіз фірмових стилів авіакомпанії, що провадять діяльність на території України, свідчить, що найбільш уживаним типом логотипу є комбінований, в якому поєднується графічне зображення і текстовий напис, найчастіше - назва компанії. Також використовують схожий набір фірмових кольорів в різних комбінаціях, а саме: червоний, жовтий, білий та синій. Такий вибір обумовлений як емоційним впливом, так i символічним навантаженням кольорів. Синій означає спокій, впевненість, безпечність, що досить часто є провідними ідеями провадження діяльності компаній. Жовтий колір пов'язується з перспективністю, надіями, мріями. За фізіологічним ефектом жовтий схожий з червоним, він так само збуджує, проте виконує цю функцію більш м'яко, акуратно. Білий пов'язують з чистотою, урочистістю, миром, спокоєм, свіжістю.

Фірмовий дизайн авіакомпаній підпорядковується загальним особливостям розробки і проєктування елементів фірмового дизайну з урахуванням специфіки діяльності, що провадять ці компанії, сталих тенденцій в презентації авіакомпаній, як в основних елементах фірмового стилю, так і у візуальній представленості компаній в мережі інтернет (на сайтах або за допомогою мобільних додатків). Сучасним компаніям для розширення представлення власних послуг потенційним кліснтам, підвищення авторитету компанії і формування суспільної довіри необхідна присутність в інтернеті, яку можуть забезпечити сайт 154 
та / або мобільний додаток. Розробка сайту і мобільного додатку має відбуватися з урахуванням фірмового стилю, де головними скеровуючими компонентами є логотип, фірмові кольори і фірмові шрифти. Проєктування макетів сучасних сайтів підпорядковується як запитам ринку, так і природньому розвитку процесу проєктування, тенденціям у проєктуванні. Вимогами, що мають бути реалізовані в проєкті, $\epsilon$ зручність користування інтерфейсом, практичність, наочність та інтуїтивна зрозумілість.

Уявлення про проєктування макету сайту або мобільного додатку як виключної творчої роботи з кольорами та графікою є досить обмеженим, оскільки цей процес може передбачати: осмислення функціональності продукту, аналіз конкурентів, аналіз потенційних споживачів, дизайн дослідження, брендінг та розробка графіки, аналіз структури продукту, розробка контенту, анімації, врахування тенденцій в області дизайну, i веб-дизайну зокрема.

Початок роботи над розробкою концепту фірмового стилю авіакомпанії «AirCompany» був пов'язаний зі складанням брифу i аналізом відповідей на питання брифу. Бриф на розробку концепту фірмового стилю авіакомпанії містив огляд бренду, опис проєкту, цілей, цільової аудиторії, конкурентів, особливостей фірмового стилю, прикладів існуючих робіт і рекомендацій про те, чого слід уникати. Після опрацювання брифу першим відбулося визначення фірмових кольорів, оскільки їх вибір міг вплинути як на форму графічних компонентів логотипу, контрастність компонентів логотипа, так і на емоційне сприйняття елементів фірмового дизайну в цілому. Згідно брифу в якості фірмових кольорів були обрані кольори неба (ними стали фірмові кольори компанії синій \#265078 і блакитний \#6CE5F3). Менш жорстке обмеження стосувалося кольорів для ілюстрацій або фотографій, якщо вони не заважали функціональності інших компонентів мобільного застосунку.

Наступним етапом став паралельний пошук графічного елементу логотипа і фірмового шрифта. Перші ескізи передбачали проєктування комбінованого логотипу, але після аналізу отриманого фідбеку було вирішену змінити тип логотипа на іконічний. В результаті пошуків $\mathrm{i}$ аналізу відібраних шрифтів було обрано шрифт M PLUS Rounded 1c, перевагою якого стало гармонійне поєднання 3 логотипом, наявність в гарнітурі шрифта як кириличних літер, так i латини, шрифт $\epsilon$ безоплатним, гнучким, має багато накреслень, від тонкого до жирного.

Надалі, до проєктування зовнішнього вигляду макету сайту або мобільного додатку, необхідно було опрацювати потоки задач, user-flow, алгоритм дій на сайті та фреймворк верхнього рівня, що є запорукою 
вирішення базових завдань дизайну сайту. Фреймворк - це інтерфейс користувача, який оточує контент і допомагає користувачеві виконувати дії, переміщатися по контенту. Фреймворк містить навігацію, бічні і нижні панелі. Таке попереднє планування макета сайту дає чітке уявлення про те, що необхідно розташувати в макету при розробці розділів за межами головної сторінки. Щодо структури мобільного додатку, тут працював принцип: чим простіша, тим краще. Кожен розділ має мати закінчений змістовий результат (є зміст, причина та кінцевий результат для користувача). На сторінці (екрані, в блоці) не повинно бути занадто багато закликів до дії. Необхідні компоненти додаються до максимально простої структури, що реалізує завдання кожного окремого блоку.

Найпростішим способом презентації проєкту є демонстрація блоків на мокапах або опублікованого розробленого концепту на платформі Behance. Найкращим способом перевірити взаємодії та технології і продемонструвати роботу сайту чи мобільного додатку, зацікавити клієнта та наочно познайомити його 3 реалізованими концепціями та ідеями є прототипування.

Проєктування макетів сайтів авіакомпаній підпорядковується запитам ринку на конкретно окресленій території, природньому розвитку процесу проєктування у веб-дизайні, що має розглядатися в загальному суспільному полі, а також сталими тенденціям у галузі проєктуванні дизайну макетів сайтів і мобільних додатків. Розроблений фірмовий дизайн став основою проєктування макету сайта і мобільного додатку компанії «AirCompany». Макет сайта і мобільного додатку розроблявся у відповідності до розглянутих тенденцій розвитку веб-дизайну, принципів проєктування веб-сайтів та усталеної в галузі веб-дизайну етапності виконання проєкту та його презентації.

\section{Література:}

1. Продан I. Тотожність понять «айдентика» та «фірмовий стиль» у графічному дизайн. Вітчизняна наука на зламі епох: проблеми та перспективи розвитку : зб. мат. всеукр. наук.-практ. інтернетконференції, м. Переяслав-Хмельницький, 22 січня 2019 р. ПереяславХмельницький, 2019. № 48. С. 30-33.

2. Жаркова В. С., Обласова О. І. Фірмовий стиль, як технологія просування бренду. Масова комунікація у глобальному та наиіональному вимірах. 2019. № 11. С. 41-46.

3. Гніденко М. С., Колесніков В. В. Дизайн логотипу як основи фірмового стилю. Вісник Київського національного університету технологій та дизайну. Серія : Технічні науки. 2015. № 1. С. 73-78. 
URL: http://nbuv.gov.ua/UJRN/vknutdtn_2015_1_11 (дата звернення: 06.12.2021).

4. Бажеріна К. В., Писаренко Н. Л., Подолян О. О. Сучасні тенденції ціноутворення на ринку пасажирських авіаперевезень в Україні. Ефективна економіка. 2021. № 2. DOI: 10.32702/2307-2105-2021.2.105. URL: http://www.economy.nayka.com.ua/?op=1\&z=8712 (дата звернення: 06.12.2021).

\title{
DOI https://doi.org/10.30525/978-9934-26-178-7-40
}

\section{ОСОБЛИВОСТІ ПРОЄКТУВАННЯ ВЛАСНОГО БРЕНДУ}

\author{
Гетьман О. П. \\ магістрантка I курсу, викладач кафедри дизайну \\ Навчально-науковий інститут торгівлі, \\ обслуговуючих технологій та туризму \\ Продан I. В. \\ кандидат педагогічних наук, доцент, \\ завідувач кафедри дизайну \\ Луганський національний університет імені Тараса Шевченка \\ м. Старобільськ, Луганська область, Украӥна
}

Незважаючи на те, що соціальні медіа змінили тактику маркетингових брендів, іiі головні цілі залишаються незмінними, залучати та утримувати аудиторію. Ця тактика знаходить правильний баланс між розширенням можливостей клієнтів поширювати інформацію про бренд за допомогою вірусних платформ, одночасно контролюючи стратегічні маркетингові цілі власного бренду. А отже, з'являється потреба у створенні власного унікального бренду, привернення тривалої прихильності до нього на основі спільного впливу на споживача рекламних повідомлень, товарної марки, пакування, матеріалів для стимулювання збуту та інших елементів комунікації, об'єднаних певною ідеєю та фірмовим оформленням, які виокремлюють спеціаліста серед конкурентів і створюють його образ.

Актуальність теми полягає у тому, що на сьогоднішній день поняття бренд застосовується як до товару, так і до людини. У сучасному професійному світі фахівець повинен постійно просувати себе, щоб залишатися затребуваним. Персональний (особистий) бренд це - «образ, 